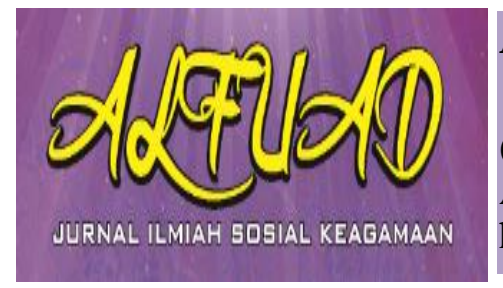

ALFUAD JOURNAL, 5 (2), 2021,(18-25)

(E-ISSN 2714-7606 P-ISSN 2614-4786 )

Available online at

http://ecampus.iainbatusangkar.ac.id/ojs/index.php/alfuad

\title{
The Influence of the Pandemic on the Yasinan Tradition of the Indonesian Society
}

\author{
Muhamad Restu Andhika Esa \\ Putra*) \\ Universitas Muhammadiyah Prof. Dr. \\ Hamka, Indonesia \\ E-mail: mrandhika8@gmail.com
}

\author{
Ahmad Ruslan \\ Universitas Muhammadiyah Prof. Dr. \\ Hamka, \\ Indonesia \\ E-mail: ruslam@uhamka.ac.id \\ *) Corresponding Author
}

\begin{abstract}
The Coronavirus pandemic has been running for over 1 year, subsequently, numerous customs and ropensities for the Indonesian public have changed. One of the changing local area customs is the yasinan custom, this practice is regularly held by Indonesian individuals one time each week. In this custom where individuals assemble and read Surah Yasin together, however this get-together practice is exceptionally opposing to be done as of now during the pandemic and when the PSBB was carried out. Along these lines, the creator is keen on directing this examination, determined to perceive how much impact the pandemic has on the yasinan custom and how individuals manage it and keep up with the practice
\end{abstract}

Keywords: Pandemic, Tradition, Yasinan

\section{INTRODUCTION}

As Indonesians, we are no stranger to the Yasinan tradition. An activity that every week on Friday nights is always carried out by the people of Indonesia. The Yasinan tradition is seen as a glue that binds people together in social relations. When participating in Yasinan events, residents who previously did not know each other now know each other. (Rodin, 2013). The participation of residents in the Yasinan event can also foster a sense of sympathy and empathy between residents and strengthen a relationship.

In events Tradition Yasinan sometimes various snacks, rice and blessings are served. This also has economic values, where mutual cooperation for the presentation of Yasinan consumption is also an economic value for the community, because it can reduce energy and time expenditure. (Rodin, 2013). In addition, there is also the value of theological and philosophical concepts in the implementation of the Yasinan Tradition which participates as a form of mental solidarity for the community (Rodin, 2013). The influence of theological concepts in this activity is when people believe that the sins they have committed against their fellow human beings can be covered by good practices that they have done during their life, by referring to the Qur'an and Hadith.(Rodin, 
2013). Then the influence of the philosophical concept of Yasinan's activities is that humans cannot live alone so humans need other humans to live. Therefore, humans must help each other among humans, especially fellow Muslims, in order to unite Muslims as a whole (Rodin, 2013). And these concepts

Traditions that are often carried out by the community in langgar, prayer room, mosque and even at homes every Friday night, have become a routine activity for the Indonesian Muslim community. The custom of the Yasinan tradition is motivated by traditions that have been passed down from generation to generation and inherited by their predecessors. Yasinan itself can be said as part of a community ritual in order to send prayers for the spirits of the dead. However, if we look at Surah Yasin, it is indeed read more often by Muslims than other surahs, because indeed in Surah Yasin it has great content and benefits (Sumarni, 2018). Surah Yasin is indeed very useful, Rasulullah SAW said "Whoever reads (letter) Yasin at night hoping for Allah's pleasure, he will be forgiven (his sins)." (HR. At Thobroni/145, 418 and AlBayhaqi/2360, 2361 from Abu Huroiroh, Ad Darimi/3478 from Hasan, authenticated by Ibn Hibban/2626). The scholars say that the specialty of Yasina is that if it is read in difficult circumstances, Allah will facilitate the affairs of those who read it. (Mubarok, 2014).

The existence of the Yasinan Tradition in the daily life of the Indonesian people creates a bond of brotherhood and strengthens a relationship in social life. The participation of citizens in participating in the yasinan event can foster a sense of empathy and sympathy for the community to share what is felt by the community holding the yasinan event. (Hayat, 2014). However, if you look at the current conditions, this Yasinan Tradition seems difficult to do. Looking at the current conditions, the pandemic has been going on in Indonesia for more than a year. The ongoing Covid-19 pandemic has claimed lives, with that the government issued policies to combat this pandemic. From the PSBB to PPKM policies, it has been running at this time. The health protocol has now been tightened, so that it has an impact on community activities. One of them is Yasinan's activities.

This yasinan activity has become a tradition for the Indonesian people, but at times like this it is difficult to implement. So that the Yasinan Tradition has not been carried out in several areas by the community, because it is feared that it will create a cycle of spreading the Covid-19 virus. However, there are actually several ways to keep this Yasinan Tradition running during the pandemic without 
compromising the essence of the activity. By utilizing existing media, such as video conferencing media that exist today. So that the impression of togetherness, friendship, and religious activities is maintained even though online.

\section{METHOD}

A qualitative approach with descriptive method is used in this study, where the data collected is in the form of words, pictures and not numbers. According to Bogdan and Taylor as quoted by Lexy J. Moloeng, qualitative research is a research procedure that produces descriptive data in the form of written or spoken words from people and observed behavior (Prof. DR. Lexy J. Moleong, 2018). While descriptive research is a form of research that aims to describe or describe existing phenomena, both natural phenomena and human engineering (Prof. DR. Lexy J. Moleong, 2018).

The author's goal is to use a qualitative approach with a descriptive method to make systematic, factual, and accurate jokes about facts. Because the context of writing this article tries to reveal the related phenomena during the pandemic by looking at its impact on the yasinan tradition of the Indonesian people.

The technique in this research is documentation, which is looking for data about things or variables in the form of notes, books, papers or articles, journals and so on. (Arikunto, 2010). Then in the technique of analyzing the data, the author uses the technique of library research or library research. Mustika Zed in (Mestika Zed, 2004) argued that literature study is a series of activities that are related to library data collection techniques such as reading, taking notes, and research materials to the stage of drawing conclusions.

\section{RESULT AND DISCUSSION}

\section{The Yasinan Tradition of Indonesia}

The Yasinan tradition has indeed become a routine tradition that the Indonesian people continue to carry out every week. The Yasinan tradition is a religious activity that is often carried out by the Muslim community in the context of offering prayers or istighfar, reading Surah Yasin and tayyibah sentences which are given to spirits who have died (Nasyit Manaf, 2017). This tradition is carried out every Friday night after the Isha prayer, and is usually carried out by Indonesian people in mosques or residents' homes in turns every week.

The Yasinan tradition carried out every Friday night has a reason why the time of its implementation is Friday night. Because Friday is a special day, when compared to other days (Hari, n.d.). According to Ibn Qayyim, Friday is a day of worship. This Friday is sayyidul ayam 
(the master of other days). In addition, this Friday is yaumul mazid, which means the day on which Allah will tajalli (appear) to those who believe in heaven later. That is all. Another specialty of Friday is that many sins are forgiven.

This tradition is usually carried out by being led by a local cleric or ustadz (Mubarok, 2014). The Yasinan tradition has a series of activities, starting with reciting the creed together and continuing with the reading of the muqoddimah by the ustadz. Then after that together read Surah Yasin which was continued by reading Surah Al-Ikhlas, Surah Al-Falaq and Surah An-Nas. Then after that read tahlil, tasbih, tahmid, istighfar, blessings and other verses. And usually closed with a prayer reading by the ustadz (Mubarok, 2014).

The existence of the Yasinan Tradition in the daily life of the Indonesian people creates a bond of brotherhood and strengthens a relationship in social life. The participation of citizens in participating in the yasinan event can foster a sense of empathy and sympathy for the community to share what is felt by the community holding the yasinan event. (Hayat, 2014). In the Yasinan tradition, the values of goton-royong are also inserted. Usually during the implementation, after the Yasinan series of events are completed, residents have a meal together. During the process of serving food, residents work together to make dishes that have been financed by the host who has an intention. Because of this, the Yasinan incident greatly affected people's lives. The Yasinan Tradition can foster solidarity in people's lives, because there is a sense of helping each other (Hayat, 2014).

\section{The Fate of The Yasinan Tradition During the Covid-19 Pandemic}

The Covid -19 pandemic that hit Indonesia was first confirmed that there were people who were positive for COVID-19 on March 2, 2020. The sprea of the COVID-19 virus has recently experienced a very wide increase. This can be seen, almost all regions of Indonesi have residents who are positive for COVID-19(Maruf,2021). This pandemic has impacted all aspects of people's lives. This is due to the increasing number of deaths due to the Covid-19 virus.

With conditions like this, the government continues to make policy after policy to combat the pandemic in this country. This was done because the number of positive Corona began to continue to increase. Then to suppress the positive number of Covid-19, the government immediately took action by issuing a legal basis to accelerate the handling of the corona virus. One of them is Large-Scale Social Restrictions or PSBB which is regulated in $\mathrm{PP}$ number 21 of 
2020. This PSBB is intended to reduce the number of mass crowds which can become a cycle of spreading the Covid 19 virus.

When the PSBB policy came into effect, many people canceled Yasinan's activities in advance, with the intention of delaying it so that there would be no crowds. If you look at the Yasinan Tradition activities that are often carried out every week by the Indonesian people, they invite the masses. Because in its implementation, gathering in one place, this is indeed very contrary to the PSBB policy. In addition, a new policy is currently being issued, namely the Implementation of Emergency Community Activity Restrictions (PPKM) to tighten community activities to prevent the spread of Covid-19 in Indonesia.

This PPKM policy has been implemented since 3-20 July 2021 with a focus on being implemented in Java-Bali. According to the explanation of the Minister for the Economy, Airlangga Hartanto, he explained that during this emergency PPKM, health protocols will be carried out with law enforcement. This makes Yasinan Tradition activities difficult to carry out, due to the strict rules in enforcing this policy. This activity was replaced by reading Surah Yasin individually in their respective homes.

\section{A New Step for The Community in Carrying Out Yasinaan Activities During a Pandemic}

Currently, it is very difficult to carry out activities to gather or gather mass. Due to the ongoing Covid-19 pandemic. In various parts of Indonesia, activities whose purpose is to gather are eliminated. One of them is the Yasinan activity, an activity which has become a tradition for the people of Indonesia. But this activity actually can still be carried out during the current pandemic. By utilizing existing technology at this time.

In today's technological developments, many media media continue to develop in helping and improving human performance. We'll see, when a pandemic hits the world in an instant, changes occur in all parts of the world. Where the whole community is asked to carry out activities and work based on WFH (Work From Home).

With this, there are various digital technologies that can be used to facilitate work, study, public health, and all human activities. During the COVID-19 pandemic, technology plays an important role in maintaining the function of community activities during Large-Scale Social Restrictions (PSBB) (Komalasari, 2020).

There are so many media that are the result of technological development 
that can help overcome problems during a pandemic. Such as the problem in carrying out Yasinan activities during the pandemic. The public can use video conference media such as Zoom Meeting and Google Meet as a means to gather and carry out Yasinan activities during the pandemic. Technically it is still the same, led by an ustadz or religious leader and followed together by the residents. But the difference is only in their activities. Where usually finished yasinan is given a food treat is now abolished. This can also reduce the budget for carrying out Yasinan activities, where the community's economy is declining due to the Covid-19 pandemic.

Although the implementation is not directly gathered, Yasinan using the online method through a video conference platform does not reduce the value of togetherness contained in Yasinan activities. Yasinan's online activities, apart from the main purpose of carrying out religious rituals, can also maintain the relationship between communities. People can still gather and chat together without worrying about causing clusters to spread Covid-19.

The essence of Yasinan's activities has also not changed. the value of togetherness remains and is maintained. This is also a new step for residents during a pandemic like this, to maintain friendship. The article is that when the pandemic hit, the interaction between residents was greatly reduced. Therefore, the existence of online Yasinan activities can be a means of interaction for residents. From here, residents can also know the conditions between fellow citizens because of the interactions that occur in Yasinan's online activities.

\section{The Effectiveness of the Implementation of Online Yasinan Activities for Indonesian Society}

The implementation of online Yasinan activities should be effective during a pandemic like this. Where at this time it is true that community activities related to mass gatherings are eliminated. With the use of video conference application media such as Zoom Meeting and Google Meet, it can indeed be used as an alternative to overcome problems in community gathering activities. By utilizing video conferencing media has a good role, especially if it is done properly (Monica \& Fitriawati, n.d.).

Yasinan's online activities are indeed a solution during a pandemic like this. However, there are several things that must be considered for the accuracy of using video conference media in these activities, for the smooth continuity of their activities. In this Yasinan activity, the community at large, both teenagers and fathers. Collaboration is needed, because not all people understand the operation of 
the video conference media. From here, it is necessary for the role of teenagers to become tutors to operate the video conference media, because teenagers are now accustomed to using video conference media in their education and work activities. (Komalasari, 2020). With the collaboration in providing an understanding of the use of video conference media, the Yasinan Tradition activities can at least be carried out.

In addition, there are things that seem to still need to be considered again, namely the available internet connectivity. This is because not all areas of Indonesian society have good connectivity, besides that there are also supporting tools such as smartphones and PCs/laptops that are needed by the community to carry out these activities. And what you need to know is that not all Indonesian people can fulfill these supporting tools. Therefore, it seems that this online Yasinan tradition activity cannot be carried out widely by all levels of society, when viewed from the condition of the community. However, online Yasinan activities can be one solution to preserve the Yasinan Tradition during a pandemic like this, provided that not all levels of society can do it.

\section{CONCLUSION}

This yasinan action has become a custom for the Indonesian public, yet on occasions such as this it is hard to carry out. The Yasinan Tradition has for quite some time been eliminated in certain spaces by the local area, since it is expected that it will make a pattern of spreading the Covid-19 infection. Nonetheless, there are really a few different ways to keep this Yasinan Tradition running during the pandemic without compromising the substance of the movement. By using existing media, for example, video conferencing media that exists today. So the impression of fellowship, kinship, and strict exercises is kept up with despite the fact that on the website.

\section{REFERENCES}

Hari, K. (n.d.). Keutamaan Hari Jum'at. 14.

Hayat. (2014). Strategi Dakwah Nu Dalam Membangun Mental dan Karakter Masyarakat. 297-320.

Komalasari, R. (2020). Manfaat Teknologi Informasi dan Komunikasi di Masa Pandemi Covid 19. 38-49.

Manaf, N. (2017). Sejarah dan Asal-Usul Yasinan di Indonesia Dilengkapi dengan Dalil dan Shahih. Slamidia.Com.

https://islamidia.com/sejarahdanasal-usul-yasinan-diindonesiadilengkapi-dengan-dalilshahih/

Maruf, E. (2021). "Setahun Corona di Indonesia, Begini Kondisi Terkini Pasien Pertama Positif Covid". Inews.Id.

https://jateng.inews.id/berita/2- 
$\underline{\text { maretsetahun-corona-di-indonesia- }}$

beginikondisi-terkini-pasien-

pertamapositif-covid

Mestika Zed. (2004). Metode penelitian kepustakaan. Jakarta: Yayasan Pustaka Obor Ind onesia.

Moleong, Prof. DR. Lexy J. M. (2018). Metodologi penelitian kualitatif. PT Jakarta: Remaja Rosdakarya.

Monica, J., \& Fitriawati, D. (n.d.). Efektivitas Penggunaan Aplikasi Zoom Sebagai Media Pembelajaran Online Pada Mahasiswa Saat Pandemi Covid-19. 1630-1640.

Mubarok, M. H. (2014). Pembacaan Surah Yasin dalam Tradisi Yasinan Setiap Malam Jumat. 22(2), 1-8.

Rodin, R. (2013). Tradisi Tahlilan Dan Yasinan. IBDA: Jurnal Kajian Islam Dan Budaya, 11(1). 76-87. https://doi.org/10.24090/ibda.v11i1. $\underline{69}$

Sumarni. (2018). Persepsi Masyarakat Islam Terhadap Tradisi Yasinan pada Malam Jumat (Studi Kasus Pondok Pesantren An-Nahdlah). Makassar: Universitas Hasannudin. 